\title{
Urbanisation and Growth of Slum Population in Jharkhand: A Spatial Analysis
}

Rahul Harshwardhan $^{+*}$ and Dr V.K. Tripathi

\section{Abstract}

The objective of this paper is to examine the relation between the pace of urbanisation and growth of slum population in Jharkhand. This paper also attempts to analyse the trends and patterns of growth of slum population at the district level in Jharkhand. In terms of urbanisation process of India, slums have become an integral part of urban scenario. In India, rapid growth of slums is the result of rural-urban migration of the rural poor to the cities/towns in search of employment in the last two decades. In the absence of any affordable housing, there has been growth of slums in the urban areas of the country. In India, out of a total population of 1.21 billion, $31.30 \%$ population resides in the urban areas, but $21.68 \%$ (61.8 million) of the total urban population live in the slums. Slums are considered as a major problem within the urban areas, particularly in relation to the issues of transportation, population growth, health and safety. The developing states or regions of India are more prone to this problem due to the lack of infrastructural development and heavy urban population pressure. Like other states of India, Jharkhand too is facing the problem of slums. After its separation from Bihar in 2000, the rate of urbanisation and the rate of growth of slums had gone high. The study reveals that in 2001, there were only 11 urban centers consisting of slum population but in 2011, it reached to 31 . The slum population registers $23.68 \%$ growth while the urban population growth stands at $32 \%$. This paper is primarily based on secondary data collected from different governmental agencies, particularly the Census data of population to analyse the spatial distribution of slum population in the districts of Jharkhand. This study explores the changing urbanisation scenario in Jharkhand and the growth of slums with respect to it.

Key words: Slum, Urbanisation, Growth of Slum, Jharkhand, India

\footnotetext{
† Junior Research Fellow, Department of Geography, Banaras Hindu University, Varanasi-221005, Email: harshwardhan.rahul20@gmail.com, ${ }^{*}$ Corresponding Author

İAssociate Professor, Department of Geography, Banaras Hindu University, Varanasi-221005,

Email: vktbhu2004@gmail.com

C2015 Harshwardhan and Tripathi. This is an Open Access article distributed under the terms of the Creative Commons Attribution License (http://creativecommons.org/licenses/by/2.0), which permits unrestricted use, distribution, and reproduction in any medium, provided the original work is properly cited.
} 


\section{Introduction}

The true essence of urbanisation lies in the rapid growth of population in the urban areas and economic activities. An urban area can be identified on numerous criteria like administrative, occupational structure, population size and density. In India the most popular and effective criteria considered for urbanisation is that of size of the population and administrative structure. Bhagat (1992: 10) have identified mainly three attributes, which contributes to urbanisation, first natural increase, second net migration and third areal reclassification. According to Ramchandran (1989:82), "urbanisation is essentially an economic process". This means that identity of an area changes with the diversification of the activities being performed. Sawhney (2013: 48) argues that "in countries like India, where over population is a major hindrance to growth, slums crop up in the vicinity of urban settlements within days. In India most of the metros, industrial and service towns and cities have slums around or at any other location within the city circumference". The overconcentration of fiscal resources and unplanned urban growth are generating regional disparity leading to the growth of slums in the urban areas. For the first time in the 1991Census, slum population data have been recorded in the towns having population of 20,000 or above. According to the 2011 Census, a population of 377 million resides in the urban areas while it was only 20 million in 1901. The development of railways, the construction of roads and highways, establishment of new town for industries and refugees after partition following India's independence in 1947 had led to the increase in the urban population of India. Jharkhand, the new state carved out from Bihar in 2000, had witnessed tremendous urbanisation rate in the last decade of 2001-2011. In 1901, the total urban population of Jharkhand was only 117 , 975 comprising of only 13 towns and $1.94 \%$ of the total urban population of India but today the picture has totally changed. In India, the Central Government, through the office of the Registrar General of India's national sample survey office, have their own definition in the same way as each State has its own definition of slum.The National Sample Survey Organisation defines slum as: "a slum is a compact settlement of at least 20 household with a collection of poorly built tenements, mostly of temporary nature, crowded together usually with inadequate sanitary and drinking water facilities in un hygienic condition."Though these slums are more prevalent in the metropolitan cities of India, these are growing slowly in other cities and small towns of India too.

\section{Database and Methodology}

The present study is mainly based on the secondary data gathered from the Census of India from 2001 and 2011. Reports on slum development by the Government Agencies have been studied to understand the reality. The collected and compiled data have been analysed using MS-Excel and map have been prepared by the software Arc Gis 9.3 for a comparative analysis of the variables.

\section{Objectives}

- To study the trend and pattern of urbanisation in Jharkhand and its causes.

- To examine the relation between urban population growth and slum population.

\section{Urbanisation in Jharkhand}

Urbanisation in Jharkhand started way back in the 17thCentury. Many chiefs who had their own capital of the state ruled the whole region and these centres were distinct from the rural landscape. Because of its rugged topography and dense forest the state got its name Jharkhand. During the period of King Ashoka (273 B.C.E to 232 B.C.E), this area was called 'Atavi' which means forest state. In the time of Mughal's (1526 C.E to 1857 C.E), it was known as 'Kokrah'. With the onset of the British regime (1857 C.E to 1947 C.E) the construction of the railways and road networks had resulted in the emergence of the new urban centres. The British also stimulated the growth of the pre-existing administrative centres. The urban centres that grew during the British period 
were functional in nature. For example, centres like Hazaribagh and Chatrawere developed as regimental centres for the army. Ranchi and Hazaribagh were the Christian centres in Jharkhand. Before 1901, there were only 13 towns in Jharkhand. However in 1951, it increased to 35, resulting in 22 new towns. According to the Census 2011, there are total 228 towns and urban agglomerations in Jharkhand. The city of Jamshedpur was the first in Jharkhand to become a Class I city. ${ }^{1}$ In Jharkhand, many towns owes their origin and growth because of the concentration of mining of minerals like mica and coal, and the introduction of railways in these centres by the British for transportation of these minerals to the ports and towns, namely, Koderma, Ramgarh, Jharia, Bokaro, and Dhanbad. On 14 November 2000, the state of Jharkhand was bifurcated from Bihar. Soon after independence, the process of industrialisation alongside 5-year planning was adopted for the economic development of the country. The rate of urbanisation in regions of Jharkhand was very high when it was in Bihar because of the concentration of industries and mining of minerals. The establishment of Steel plants in Bokaro, Jamshedpur, Damodar Valley Corporation has accelerated the growth of urbanisation from 1951 to 1971 . The growth rate of urban population in Jharkhand began to decline after 1971 because of stagnation in industrial development due to change in planning approach in 5-year plans. In 1981, the urban population growth declined moderately to $56 \%$, but in 1991 and 2001 urban population growth rate declined sharply to $29 \%$ and $28 \%$ respectively because of less migration of population to urban centres and sluggishness in the process of industrialisation.

Jharkhand ranks 15th in terms of its total area in the country, embracing a population of 33.5 million (Census of India 2011) constitutes 2.72\% of the total population of India. The total population of the state had increased from 6

\footnotetext{
${ }^{1}$ According to the Census of India, there is Six Class of towns based on population size: Class I: $<100,000$, Class II: 50000-99999, Class III: 20000-49999, Class IV: 1999910000, Class V: $9999-5000$ and Class: VI: $>5000$.
}

million in 1901 to 32 million in 2011. Jharkhand shares $2 \%$ of the total urban population of India. However about $24 \%$ of the total population of Jharkhand resides in the urban areas. Indeed the population of Jharkhand increased five-fold in 100 years (Table 1). The average urban population growth rate of Jharkhand is higher than that of India's growth rate except for during 1951-61 and 1971-81. The unstable political conditions throughout the country just after independence had led to the decline of urban population growth from 1951-61. In 1971 Census, new concept of urban centre was adopted because of which many urban centres degraded to rural status that resulted in the decline in urban population growth rate from1971-81. Annual urban population growth was $2.9 \%$ between 1991 and 2001 in Jharkhand compared to $3.1 \%$ at an allIndia level. The pace of urbanisation in Jharkhand had always been more than that of India. There had been continuous increase the in rate of urban population growth. However, after 1981, the speed of urbanisation became slow due to slow pace of industrialisation and lesser migration of population to the towns. In 1971, the all India total population growth rate was $25 \%$ but in Jharkhand, the urban population grew at $70 \%$. The reasons for high urban growth in Jharkhand during 1951-71 are development of basic industries in the Chotanagpur belt. In 2004-05, 11\% of the working population in Jharkhand were engaged in mining and quarrying, utility services and in construction sites, which increased to $23 \%$ in 2009-10. In the urban centres of Jharkhand, major working populations are classified in the main worker other in category. ${ }^{2}$ For instance $79 \%$ each in Ranchi and Dhanbad, $76 \%$ in Bokaro and $91 \%$ in Jamshedpur belongs to the main worker other category. This signals that

\footnotetext{
${ }^{2}$ According to the Census of India, main worker other category are those workers who had not worked for the major part of the reference period (that is, less than 6 months). The type of workers that come under this category of 'OW' include all government servants, municipal employees, teachers, factory workers, plantation workers, those engaged in trade, commerce, business, transport banking, mining, construction, political or social work, priests, entertainment artists, etc.
} 
majority of the working population are engaged in the formal sectors like mining, quarrying, vending, labour, etc. (Table 2). The total population of the state grew by $22 \%$ during 2001-11, whereas the growth of urban population had been much higher at 33\% during this period (Table1). In 2001, the share of urban population to the total population of Jharkhand was $22.24 \%$, which increased to $24.05 \%$ in 2011 (Table1). Because of the industrial and mining activities, Jharkhand is more urbanised than other states like Bihar,
Madhya Pradesh, and West Bengal. The level of urbanisation of Jharkhand is less than the national average and almost half of the urban population of the states like Tamil Nadu and Maharashtra. Most of the districts in Jharkhand have a very low level of urbanisation. Only four of the districts of this state are highly or moderately urbanised-Purbi Singhbhum (55\%), Dhanbad (52\%), Bokaro (45\%) and Ranchi (35\%) are the districts with more than one-fourth of its population inhabiting in the urban areas.

\begin{tabular}{cccccc}
\multicolumn{2}{l}{ Table 1: Urbanisation in Jharkhand (1901-2011) } \\
Census Year & $\begin{array}{c}\text { Total Number } \\
\text { of Towns }\end{array}$ & $\begin{array}{c}\text { Total Urban } \\
\text { Population }\end{array}$ & $\begin{array}{c}\text { Urban } \\
\text { Population } \\
\text { \% }\end{array}$ & $\begin{array}{c}\text { Decennial } \\
\text { Growth } \\
\text { (\%) }\end{array}$ & $\begin{array}{c}\text { Urban Population } \\
\text { Growth of India } \\
\text { (\%) }\end{array}$ \\
\hline 1901 & 13 & 117,975 & 1.94 & & .03 \\
\hline 1911 & 16 & 158,827 & 2.35 & 34.63 & .79 \\
\hline 1921 & 17 & 244,010 & 3.61 & 53.63 & 1.75 \\
\hline 1931 & 18 & 322,475 & 4.08 & 32.16 & 2.77 \\
\hline 1941 & 26 & 508,252 & 5.73 & 57.61 & 3.47 \\
\hline 1951 & 35 & 760,350 & 7.84 & 49.60 & 2.34 \\
\hline 1961 & 65 & $1,333,342$ & 11.49 & 75.36 & 3.24 \\
\hline 1971 & 96 & $2,277,632$ & 16.01 & 70.82 & 3.79 \\
\hline 1981 & 101 & $3,574,045$ & 20.29 & 56.92 & 3.09 \\
\hline 1991 & 133 & $4,641,227$ & 21.25 & 29.86 & 2.75 \\
\hline 2001 & 152 & $5,993,741$ & 22.20 & 28.99 & 2.76 \\
\hline 2011 & 228 & $7,933,061$ & 24.00 & 32.97 & \\
\hline
\end{tabular}

Source: Census of India, 2011

District Level Urbanisation in Jharkhand

Table 2 shows the urban population growth and trends of urbanisation in Jharkhand in the 21st century. As mentioned earlier, the pace of urbanisation in Jharkhand got more acceleration after its separation from Bihar in 2000. Almost all the districts in Jharkhand are showing an increasing trend of urban population. Some districts have very high urban growth rate in comparison to the others due to industrialisation and infrastructural investment, but this was largely in and around large cities and upcoming industrial centres. The high urban population growth is due to rural-tourban migration and urban-to-urban migration in the form of migration from small urban areas to large cities and towns. The highest population growth was registered in Palamau district with $12 \%$ increase while the lowest was in Hazaribagh witnessing $-4.7 \%$ growth because of separation of Ramgarh as a new district from it. The new trend of urbanisation is in favour of the districts, which were not much urbanised previously like Deoghar (6.16\%), Garwah (6.33\%), Giridih (7\%), Godda (7.4\%), Gumla (6.36), Koderma (6.28\%), Latehar (9.71\%), Pakur (8.73\%), Palamau (12.87\%), Sahibganj (6.27\%), Saraikela Kharsawan (6.18\%).

These districts gained growth in urban population due to the development of industries, infrastructure and employment opportunities along with the availability of health, education, banking and other basic urban services, which were previously concentrated only in the industrialised districts of Jharkhand- Ranchi, Purbi Singhbhum, Paschim Singhbhum and Bokaro. Many new industrial units and mines had been established 
by both the government and private sector in Company built its new fuel oil depot, which acts the districts of Deoghar, Dumka, Godda, as fuel oil distributing centre for the whole of Hazaribagh where very less industrial Jharkhand. In Godda, one of the largest open development had taken place in the last cast mines of whole Asia had been constructed decades. In Dumka district, the Jindal Steel for mining coal. These big projects had brought established its power generation unit. In scope for the development of service sector Hazaribagh, Karanpura Super Thermal Power also and enhanced the urban facilities Project and Tilaiya Ultra Mega Power Project attracting more population from rural areas.

were established. In Deoghar, the Indian Oil

Table 2: Occupational Structures of Major Cities of Jharkhand, 2011

\begin{tabular}{|c|c|c|c|c|c|c|c|c|c|}
\hline \multirow[t]{2}{*}{ Population } & \multirow[t]{2}{*}{ Types } & \multicolumn{2}{|c|}{ Ranchi } & \multicolumn{2}{|c|}{ Bokaro } & \multicolumn{2}{|c|}{ Dhanbad } & \multicolumn{2}{|c|}{ Jamshedpur } \\
\hline & & Number & $\%$ & Number & $\%$ & Number & $\%$ & Number & $\%$ \\
\hline \multirow{8}{*}{ 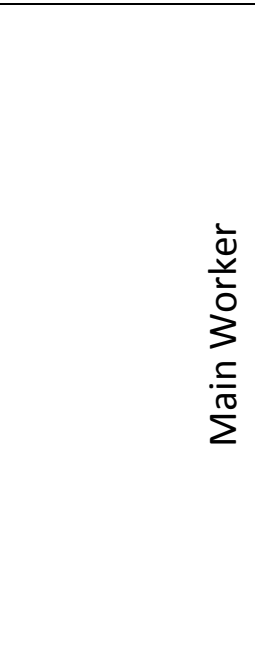 } & Main & 3252 & 0.96 & 1100 & 0.93 & 1329 & 0.41 & 274 & 0.13 \\
\hline & $\begin{array}{l}\text { Worker: } \\
\text { Cultivator }\end{array}$ & & & & & & & & \\
\hline & Main & 5896 & 1.75 & 1049 & 0.89 & 3021 & 0.94 & 941 & 0.47 \\
\hline & $\begin{array}{l}\text { Worker: } \\
\text { Agricultural } \\
\text { Labourers }\end{array}$ & & & & & & & & \\
\hline & Main & 9143 & 2.71 & 2683 & 2.29 & 6215 & 1.94 & 3380 & 1.71 \\
\hline & $\begin{array}{l}\text { Worker: } \\
\text { Household } \\
\text { Industries }\end{array}$ & & & & & & & & \\
\hline & Main & 268599 & 79.85 & 89362 & 76.34 & 252882 & 79.19 & 181267 & 91.72 \\
\hline & $\begin{array}{l}\text { Worker: } \\
\text { Other }\end{array}$ & & & & & & & & \\
\hline \multirow{14}{*}{ 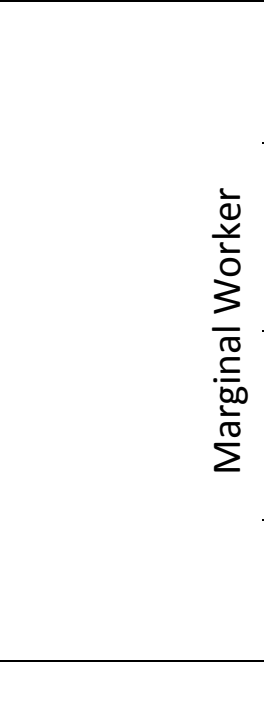 } & Marginal & 2177 & 0.64 & 2643 & 2.25 & 1047 & 0.32 & 165 & 0.083 \\
\hline & $\begin{array}{l}\text { Worker: } \\
\text { Cultivator }\end{array}$ & & & & & & & & \\
\hline & Marginal & 4955 & 1.47 & 2230 & 1.90 & 2153 & 0.67 & 258 & 0.13 \\
\hline & Worker: & & & & & & & & \\
\hline & Agricultural & & & & & & & & \\
\hline & Labourers & & & & & & & & \\
\hline & Marginal & 2667 & 0.79 & 1276 & 1.90 & 2517 & 0.78 & 562 & 0.28 \\
\hline & Worker: & & & & & & & & \\
\hline & Household & & & & & & & & \\
\hline & Industries & & & & & & & & \\
\hline & Marginal & 39669 & 11.79 & 16707 & 14.27 & 50153 & 15.70 & 10764 & 5.44 \\
\hline & Worker: & & & & & & & & \\
\hline & Other & & & & & & & & \\
\hline & Total & 336358 & & 117050 & & 319317 & & 197611 & \\
\hline
\end{tabular}




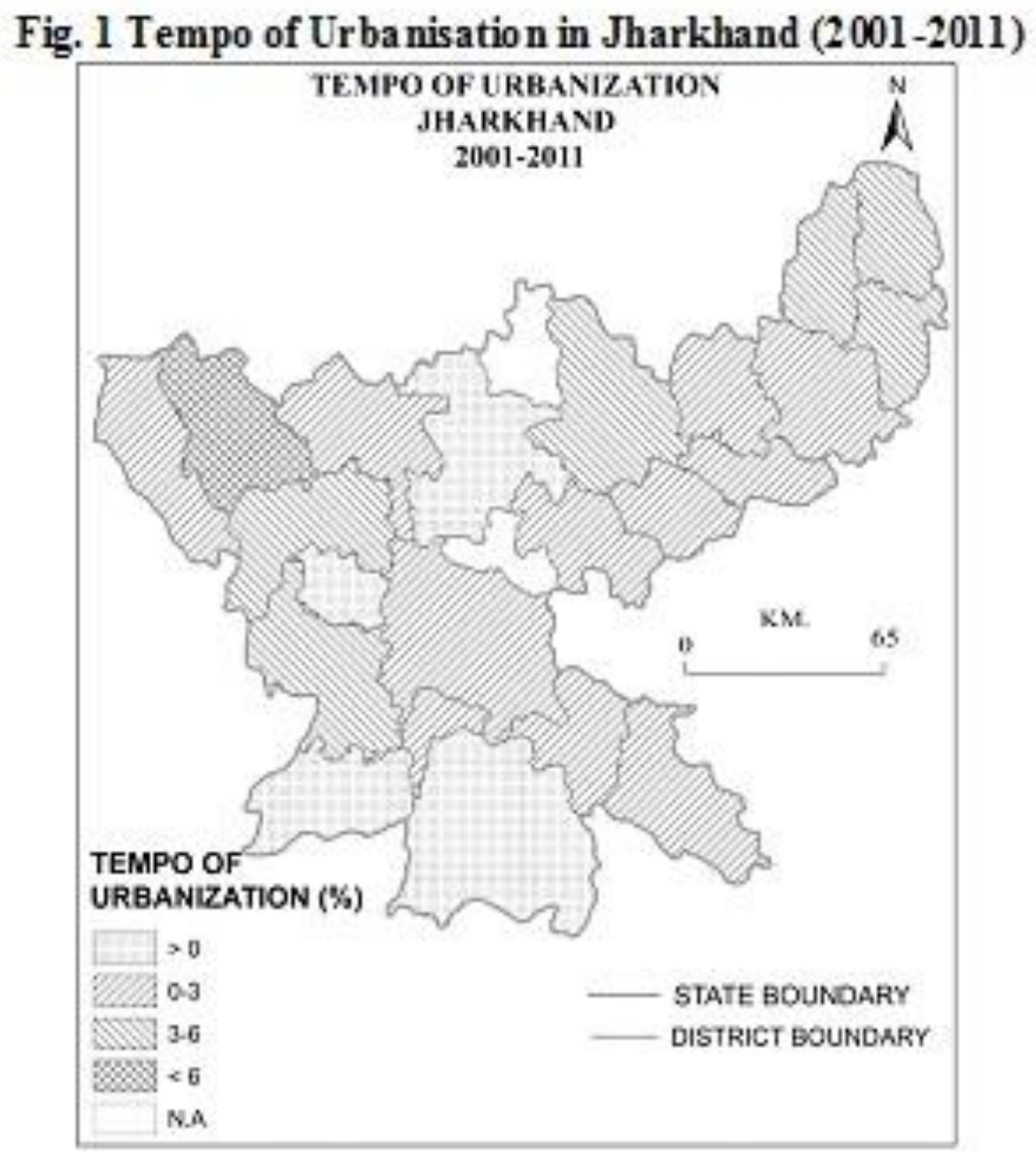

Source: Primary Census Abstract Census of India, 2011.

\begin{tabular}{llllll} 
Table 3: Urban Population Growth (\%) and Trend (\%) in Jharkhand (2001-2011) \\
District & $\begin{array}{c}\text { Growth } \\
\text { (\%) }\end{array}$ & Speed of Urbanisation & District & $\begin{array}{c}\text { Growth } \\
\text { (\%) }\end{array}$ & Speed of Urbanisation \\
\hline Bokaro & 2.22 & .53 & Koderma & 6.28 & 1.3 \\
\hline Chatra & 4.98 & 1.4 & Latehar & 9.71 & 5.2 \\
\hline Deoghar & 6.16 & 2.6 & Lohardaga & 2.42 & -0.18 \\
\hline Dhanbad & 2.42 & 1.1 & Pakur & 8.73 & 4.6 \\
\hline Dumka & 5.25 & 2.7 & Palamau & 12.87 & 8.1 \\
\hline Garhwa & 6.33 & 2.8 & PaschimSinghbhum & 1.41 & -0.6 \\
\hline Giridih & 7.00 & 3.2 & PurbiSinghbhum & 1.68 & .09 \\
\hline Godda & 7.4 & 3.8 & Ramgarh** & N.A. & N.A. \\
\hline Gumla & 6.36 & 3.3 & Ranchi & 2.85 & 2.29 \\
\hline Hazaribagh & -4.7 & -3.1 & Sahibganj & 6.27 & 3.1 \\
\hline Jamtara & 3.57 & 1.2 & SaraikelaKharsawan & 6.18 & 2.9 \\
\hline Khunti* & N.A. & N.A. & Simdega & 2.63 & .08
\end{tabular}

Source: Census of India, 2001 \& 2011,

Note: Khunti* separated from Ranchi in 2007 \&Ramgarh** separated from Hazaribagh in 2007 


\section{Level of Urbanisation in Jharkhand}

Level of urbanisation represents the total number of urban population to the total population. There is a variation in the level of urbanisation in Jharkhand ranging from $58 \%$ in Dhanbad which is highest to lowest of $5 \%$ in Godda. The districts with high level of urbanisation are Ranchi (43\%), Bokaro (47\%), Ramgarh (44\%) and PurbiSinghbhum (55\%). The high levels of urbanization are the result of high concentration of industrial complexes and mining areas in these districts. The major industrial complexes and mining areas in Bokaro district are Chandrapura, Tenughat, Gomia, Kargali, Dugda, and Chas. In PurbiSinghbhum, major industrial complexes and mining areas are Seraikella, Jojobera, Jugsalai, Adityapur, Gamharia, Musabani and Ghatsila. In Ramgarh district, major industrial complexes and mining areas are Sirka, Patratu and Ghato. While in Ranchi district, the industrial complexes and mining areas are located in Getalsud, Tupudana, Hatia, Namkum, Doranda, Gumla and Dhurwa. In these districts, the major working populations are engaged in the industries, manufacturing and mining activities. In Ranchi district, 0.15 million is engaged in engineering, mining, electrical equipment industry. In Ranchi, only $25 \%$ of the population is main workers engaged in secondary and tertiary sectors. All the districts have registered an increase in the level of urbanisation when compared to the 2001 Census. These large variations in the level of urbanisation are mainly due to the migration of rural population towards the industrialised districts for employment and basic services like health, education, banking and good quality of life. The high speed of urbanisation is found in the districts of Giridih (3.2\%), Godda (3.8\%), Gumla (3.3\%), Latehar (5.2\%), Palamau (8.1\%), Pakur (4.6\%) and Sahibganj (3.1\%). With the diversification of economic activities and rural population, determination to live a good life attracted the population to these centres. The development of transport and road networks in the last decade also provided the impetus in increasing the urban population. The upgradation of many such centres into 'notified areas'3along with the recognition as urban centres provided the boost for urbanisation. The western and southern Jharkhand which includes Bokaro, Dhanbad, Ranchi, Purbi Singhbhum, Saraikela Kharsawan, Ramgarh are more urbanised than the other parts of Jharkhand (Fig. 2). There are huge deposits of coal and iron ore in these areas, which provides facility for the establishment of industries, and large work force are required to mine out these minerals. The northern districts of Jharkhand, which includes Chatra, Deoghar, Dumka, Godda, Pakur, Koderma, Garwah, Giridih, are lowly urbanised due to the lack of development of industries and less availability of any minerals, while the eastern districts like Palamau, Lohardaga, Gumla, Latehar, Simdega, Khunti are moderately urbanised districts (Fig. 2).

There is not much varation in the level of urbanisation in Jharkhand in both Census 2001 and 2011 (Fig. 2). All the districts of Jharkhand have slow or moderate urban growth except for Palamau (12.87\%) and Saraikela Kharsawan (6.18\%). In 2001, the Hazaribagh district had $23 \%$ urban population, which decreased to $15 \%$ in 2011 because of separation of Ramgarh as separate district in 2007. In 2001, the Ranchi district had $35 \%$ urban population, which increased to $43 \%$ in 2011, although Khunti district was separated from Ranchi district in 2007, but still there is high level of urbanisation, which is due to large migration of population. It seems that the level of urbanisation in whole Jharkhand is constant in both decades. Though there is a slight incresase in the level of urbanisation in almost all districts, these increases are so meagre that it is not possible to map.

\section{Growth of Slum Population at District Level}

The 21st century Jharkhand not only sustained population growth but also more of urbanisation. The chief cause of migration to

\footnotetext{
${ }^{3}$ According to Census of India, Notified Area Council (NAC) or City Council is a form of an urban political unit in India comparable to a municipality. An urban centre with more than 11,000 and fewer than 25,000 inhabitants is classified as a "Notified Area".
} 
urban areas in Jharkhand is the economic strength of large urban centres in its contribution to employment opportunities and better means of livelihood. In Jharkhand, similar to other states of India, migration too played an important role in accelerating urban growth. The urban centres in Jharkhand like Ranchi, Bokaro, and Jamshedpur have become the attracting points for the employment seekers. However, the planned urbanisation has been marred to an extent by the excessive demand for basic amenities resulting in deterioration of the physical environment. Slums have become an integral part of the phenomenon of urbanisation, which are the result of failure of overall socio-economic policies and programmes of the states and the country. The quality of life has thus suffered due to continuous influx of migrants and increasing gap between demand and supply of essential services and other infrastructures in the urban areas.

Fig. 2 Ler el of Urbanisation in Jharkhand 2001 and 2011

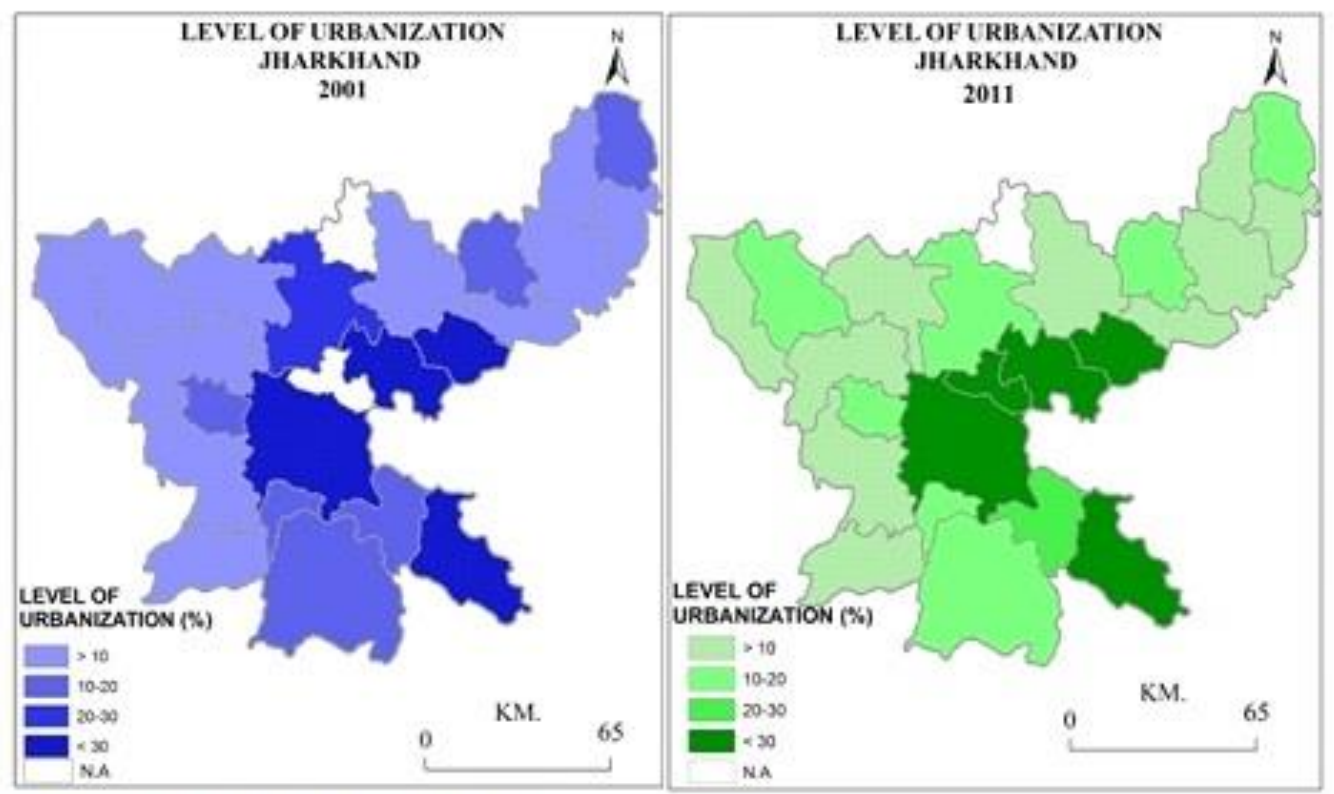

Source: Census of India $2001 \& 2011$.

\section{Table 4: Level of Urbanisation in Jharkhand (in \%), 2001-2011}

\begin{tabular}{llllll} 
Districts & \multicolumn{2}{c}{ Level of Urbanisation (\%) } & Districts & & \multicolumn{2}{c}{ Level of Urbanisation (\%) } \\
\cline { 2 - 3 } \cline { 6 - 7 } & 2001 & 2011 & & 2001 & 2011 \\
\hline Bokaro & 45.26 & 47.70 & Koderma & 17.37 & 19.72 \\
\hline Chatra & 5.30 & 6.04 & Latehar & 4.68 & 7.13 \\
\hline Deoghar & 13.71 & 17.32 & Lohardaga & 12.67 & 12.43 \\
\hline Dhanbad & 52.36 & 58.13 & Pakur & 5.13 & 7.50 \\
\hline Dumka & 5.34 & 6.82 & Palamau & 6.42 & 11.65 \\
\hline Garhwa & 4.11 & 5.27 & PaschimSinghbhum & 15.48 & 14.51 \\
\hline Giridih & 6.42 & 8.51 & PurbiSinghbhum & 55.02 & 55.56 \\
\hline Godda & 3.53 & 4.90 & Ramgarh & - & 44.13 \\
\hline Gumla & 4.77 & 6.35 & Ranchi & 35.10 & 43.14 \\
\hline Hazaribagh & 23.23 & 15.87 & Sahibganj & 10.57 & 13.88 \\
\hline Jamtara & 8.54 & 9.58 & SaraikelaKharsawan & 18.82 & 24.29 \\
\hline Khunti & - & 8.46 & Simdega & 6.60 & 7.16
\end{tabular}

Source: Census of India, 2001 \& 2011.

Note: Khunti* separated from Ranchi in 2007; Ramgarh** separated from Hazaribagh in 2007 
The total slum population in Jharkhand grew at the rate of $23 \%$, which is low in respect of the urban population growth of $32 \%$ in 2011 . In Jharkhand, there is a decrease in the average household size in the slum areas because of increase in the household and the decrease of slum population. The average household size of the slums in Jharkhand in 2001 was 5.5, while it declined to 5.1 in 2011.In the 2001 Census; only 11 urban centres of 22 districts had registered slum population, while in 2011 there are 31 urban centres of 24 districts where slums are found. The population living in the slum areas of Jharkhand in 2001 was 5\% of the urban population of Jharkhand; in 2011, it had decreased to $4.7 \%$ of the total urban population of Jharkhand. Despite the increase in the number of slums-reporting urban centres from 2001 to 2011, there is decrease in the slum population, which is a good sign of development of urban basic services.

In Jharkhand, all the districts have registered either positive or negative slum population growth. The districts where negative growth of slum population was registered are Dhanbad, Koderma, Purbi Sighbhum, and Saraikela Kharsawan (Table 6). The increase in the income of the slum dwellers had permitted them to have affordable housing and basic urban amenities. The growth of slum population in Jharkhand ranges from 548\% increase in Paschim Singhbhum to $-62 \%$ in Dhanbad. The decrease in the number of slum population in Jharkhand is due to the change in the concept and definition of slum from 2001 to 2011 Census. In Jharkhand, many districts have high slum population growth rate in comparison to the rate of urbanisation. The districts where the slum population growth rate is more than the rate of urbanisation are Chatra, Deoghar, Dumka, Giridih, Jamtara,
Lohardaga, Paschim Singhbhum, Ranchi, Sahibganj and Simdega (Table5). There are three districts - Deghar, Dumka, and Sahibganj in Jharkhand where slum population was not registered in the 2001 Census but the Census 2011 registered slum population of $9 \%, 6.6 \%$, $6.35 \%$ and $10.83 \%$ respectively in these districts (Fig.4). Map (Fig.3) shows that the north eastern and southern districts of Jhakhand have high slum population growth rate. This high slum population growth is induced by growing urban centres, such as Sahibganj, Deoghar, Dumka, Giridih, Jamtara, Chaibasa, in these districts. The migration of the nearby rural people in search of employment, mainly in manufacturing and mining sectors, is the major cause of slum growth in these urban centres. These rural migrants are compelled to reside in slum because they cannot afford formal housing. The north-western, central and south eastern districts have registered less slum population growth rate than the rate of urbanisation (Fig.3). These districts include Bokaro, Dhanbad, Garhwa, Gumla, Hazaribagh, Koderma, Latehar, Pakur, Palamau, Purbi Singhbhum, Saraikela and Kharsawan. The main causes of less slum population growth rates are improvement in housing, infrastructure and income of slum dwellers to have better access to basic services. The districts having old urban centres of the state such as Ranchi, Purbi Singhbhum, Dhanbad, Koderma, and Bokaro have witnessed low rates of urbanisation and low rates of slum population growth due to less attraction of rural migrants to these urban centres. The main reasons for less attraction are the generation of employment opportunities in urban centres of other districts, infrastructural development and availability of services like health, education, banking, etc. (Table 5).

\section{Table 5: Slum Characteristics of Jharkhand, 2001 \& 2011}

\begin{tabular}{llll} 
& $\mathbf{2 0 0 1}$ & $\mathbf{2 0 1 1}$ & Growth (\%) \\
\hline Total slum household & 54228 & $\mathbf{7 2 5 4 4}$ & 33.77 \\
\hline Total slum population & 301569 & 372999 & 23.68 \\
\hline Total urban population & 5993741 & 7933061 & 32.35 \\
\hline Household size & 5.56 & 5.1 & -7.2 \\
\hline Slum reported urban centres & 11 & 31 & 181.81
\end{tabular}

Source: Report of the Committee on Slum Statistics/Census 2010 and 2011 
Fig. 3 Growth of Slum Population in Jharkhand 2001 and 2011

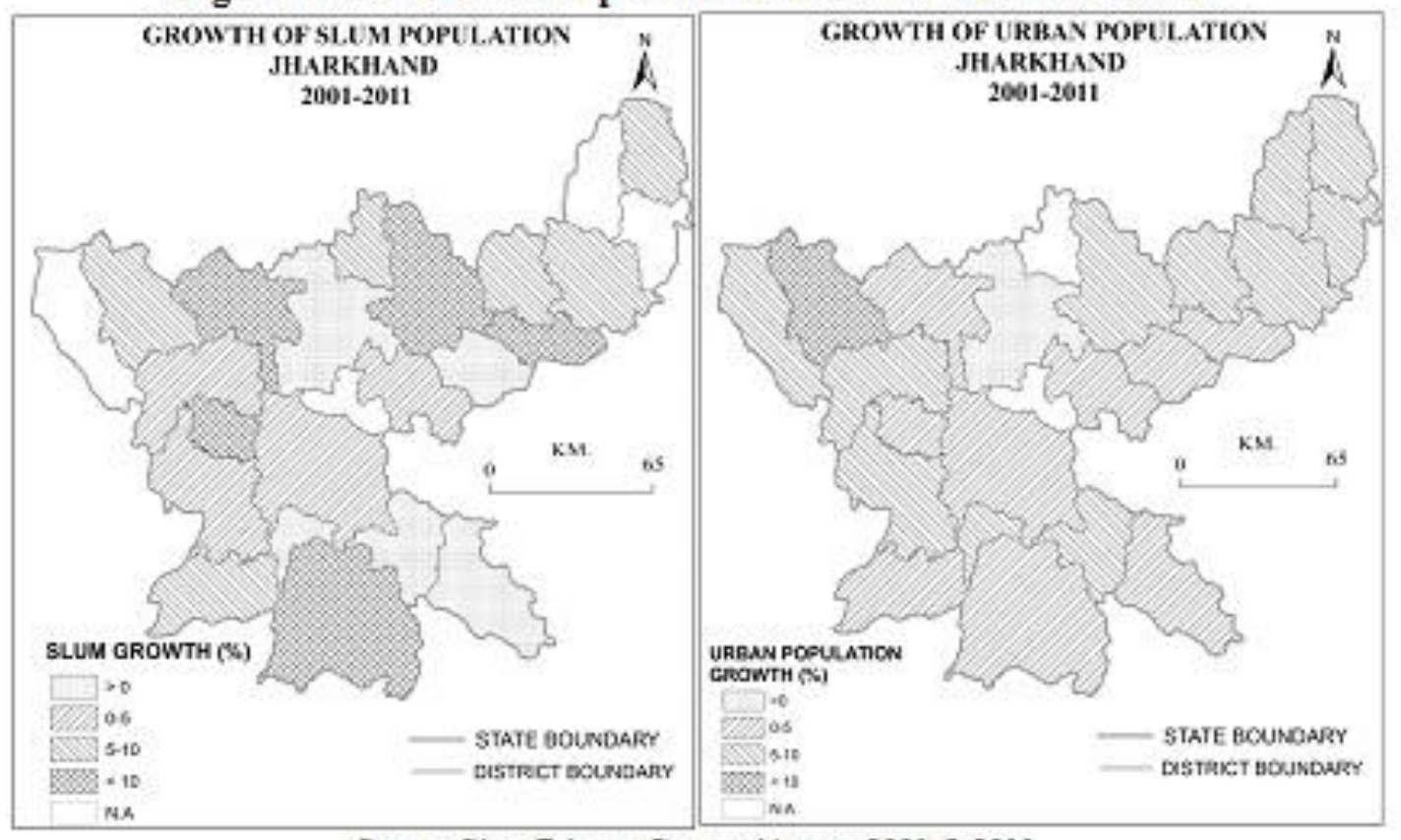

Source: Slum Primary Census Abstract 2001 \& 2011

Table 6: Growths of Urban Population and Slum Population in Jharkhand, 2001-2011

S. No. District

\begin{tabular}{llll}
\hline 1 & Bokaro & 1.08 & 2.22 \\
\hline 2 & Chatra & 10.03 & 4.98 \\
\hline 3 & Deoghar & 9.07 & 6.16 \\
\hline 4 & Dhanbad & -62 & 2.42 \\
\hline 5 & Dumka & 6.62 & 5.25 \\
\hline 6 & Garhwa & N.A & 6.33 \\
\hline 7 & Giridih & 203 & 7.00 \\
\hline 8 & Godda & N.A & 7.4 \\
\hline 9 & Gumla & 4.3 & 6.36 \\
\hline 10 & Hazaribagh & -30 & -4.7 \\
\hline 11 & Jamtara & 10.83 & 3.57 \\
\hline 12 & Khunti & 5.33 & N.A. \\
\hline 13 & Koderma & -40 & 6.28 \\
\hline 14 & Latehar & 2.8 & 9.71 \\
\hline 15 & Lohardaga & 18.00 & 2.42 \\
\hline 16 & Pakur & N.A & 8.73 \\
\hline 17 & Palamau & 7.84 & 12.87 \\
\hline 18 & PaschimSinghbhum & 548 & 1.41 \\
\hline 19 & PurbiSinghbhum & -2 & 1.68 \\
\hline 20 & Ramgarh & N.A & N.A. \\
\hline 21 & Ranchi & 4 & 2.85 \\
\hline 22 & Sahibganj & 6.35 & 6.27 \\
\hline 23 & SaraikelaKharsawan & -53 & 6.18 \\
\hline 24 & Simdega & 7.80 & 2.63 \\
\hline Saurce & Sum Primary CensusAbstact, Cens of &
\end{tabular}
Slum Population Growth Urban Population Growth

(\%)

(\%)

Source: Slum Primary Census Abstract, Census of India, 2001 \& 2011 
There are still some districts in Jharkhand, like Ramgarh, Khunti and Godda where slum population is not reported in Census 2011. The trend of urbanisation in Jharkhand shifted from Class I cities to Class II and III towns, which is evident from the high level of urbanisation and high growth rate of urban population in the districts of the Dumka (5.25\%), Godda (7.4\%), Pakur (8.73\%), Palamau (12.87\%), Sahibganj (6.27\%), Kodrma (6.28\%), Giridih (7\%) which is higher in comparison to Ranchi (2.85\%), Paschim Singhbhum (1.41\%) and Purbi Singhbhum(1.68\%). The main causes of urbanisation of these districts are development of their small towns as commercial and service centres, which provides services to small town population, which were formerly dependent on big cities/towns for services.

In the Census 2001, only eight districts in Jharkhand had registered slum population. The highest slum population was in Saraikela Kharsawan (47\%) and the lowest was in Paschim Singhbhum (1.5\%). While in 2011 Census, all the districts had recorded slum population except for in the districts of Garhwa,
Godda, Pakur and Ramgarh. In 2011 Census, the highest slum population was recorded in Lohardaga (18\%) and the lowest in Dhanbadand Bokaro (1\%). There is spatial variation in slum population in different parts of Jharkhand. The districts in Santhal Pargana region had recorded moderate and high slum population to total urban population ranging from $5 \%$ to $15 \%$ (Fig.4). The southern districts of Jharkhand, which includes, Simdega, Paschim Singhbhum, Khunti, Saraikela Kharsawan, Purbi Singhbhum had recorded moderate slum population to the total urban population varying from $5 \%$ to $10 \%$. The central districts of Jharkhand, which include Latehar, Hazaribagh, Bokaro, and Dhanbad, had recorded low slum population to total urban population in comparison to the districts of other parts of Jharkhand. The northern districts including Chatra, Giridih, Lohardaga, and Jamtara had registered moderate and high slum population to total urban population ranging from $10 \%$ to $20 \%$ (Fig.4).The less developed districts of Santhal Pargana and Southern Jharkhand had recorded moderate growth of slum population.

Fig. 4 Slum Popula tion to Total Urban Population in Jharkhand 2001 and 2011

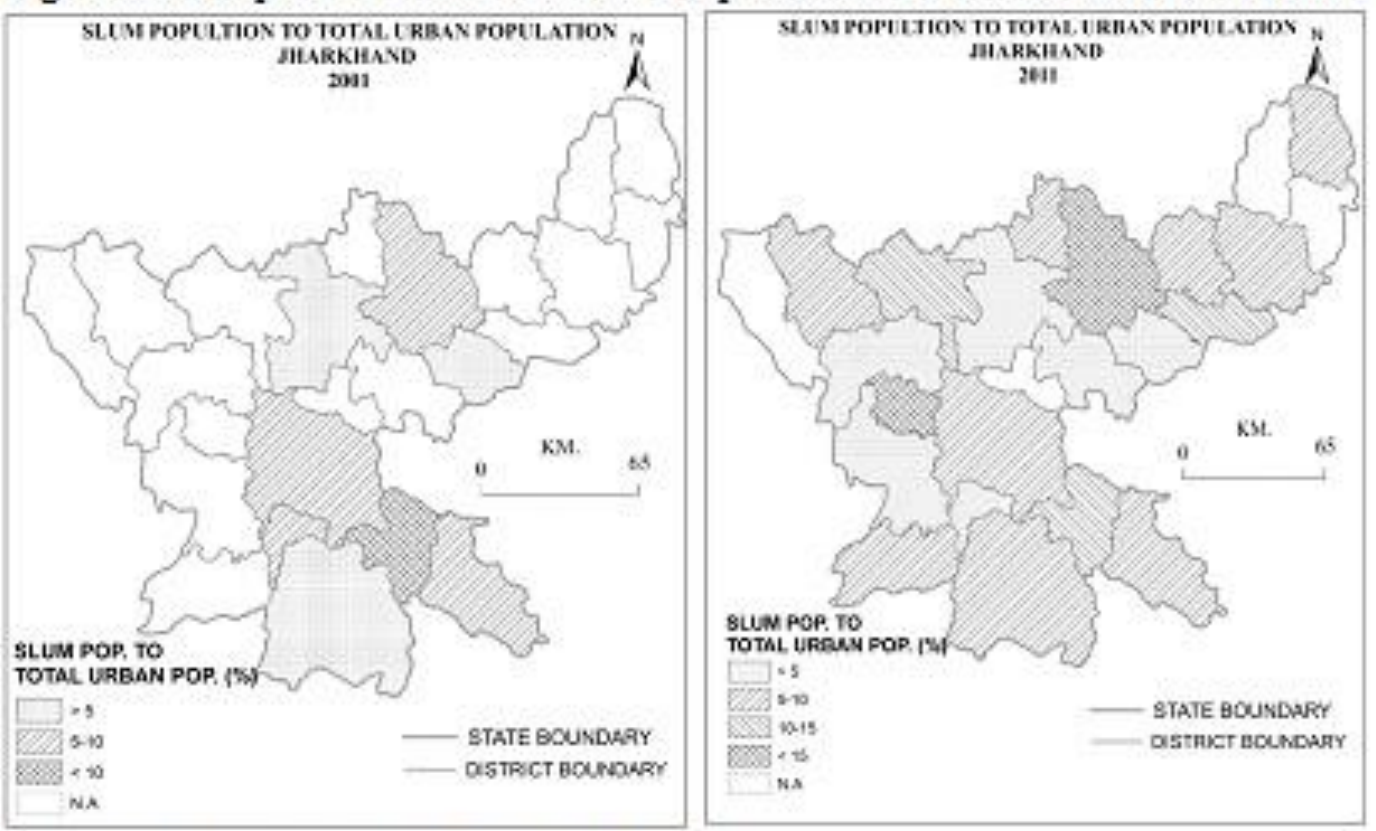

Source: Stum Primary Census Abstract 2001 \& 2011 
Table 7: Slum Population in Jharkhand and Percentage to Total Population , 1991-2011 Districts Slum Population

Slum Population to Total Urban Population (\%)

\begin{tabular}{|c|c|c|c|c|}
\hline & 2001 & 2011 & 2001 & 2011 \\
\hline Bokaro & N.A & 10667 & - & 1.08 \\
\hline Chatra & N.A & 6319 & - & 10.03 \\
\hline Deoghar & N.A & 23442 & - & 9.07 \\
\hline Dhanbad & 37579 & 14275 & 3.00 & 1.00 \\
\hline Dumka & N.A & 5975 & - & 6.62 \\
\hline Garhwa & N.A & N.A. & - & N.A \\
\hline Giridih & 11509 & 34867 & 9.5 & 16.76 \\
\hline Godda & N.A & N.A & - & N.A \\
\hline Gumla & N.A & 2824 & - & 4.3 \\
\hline Hazaribagh & 16348 & 11333 & 3.08 & 4.11 \\
\hline Jamtara & N.A & 8207 & - & 10.83 \\
\hline Khunti & N.A & 2398 & - & 5.33 \\
\hline Koderma & 6513 & 3908 & 7.5 & 2.8 \\
\hline Latehar & N.A & 1452 & - & 2.8 \\
\hline Lohardaga & N.A & 10308 & - & 18.00 \\
\hline Pakur & N.A & N.A & - & N.A \\
\hline Palamau & N.A & 17732 & - & 7.84 \\
\hline PaschimSinghbhum & 2808 & 18201 & 1.5 & 8.34 \\
\hline PurbiSinghbhum & 75924 & 74471 & 7.00 & 5.84 \\
\hline Ramgarh & N.A & N.A & - & N.A \\
\hline Ranchi & 74692 & 77602 & 7.6 & 6.71 \\
\hline Sahibganj & N.A & 10150 & - & 6.35 \\
\hline SaraikelaKharsawan & 76196 & 35515 & 47.50 & 13.72 \\
\hline Simdega & N.A & 3353 & - & 7.80 \\
\hline
\end{tabular}

Source: Slum Primary Census Abstract 2001 \& 2011, N.A: No Slum Population Reported in Census 2001

\section{Conclusion}

From the above study, conclusion can be drawn that there is direct relationship between the rate of urbanisation and the growth of slum population. In the state, the high slum population growth rate is found in the districts where high rate of urbanisation persists like in Deoghar, Chatra, Giridih, and Lohardaga. Total number of slum population had increased in 2011, but its share in total urban population had decreased because urban population growth rate is higher than the slum population growth rate in the state. In the state, with the increase in the number of urban centres, there is increase in slum reporting urban centres. In 2001 Census, there were 152 urban centres in Jharkhand out of which only 11 centres had recorded slum population but in 2011 Census, there are 228 urban centres, out of which 31 urban centres have slum population. This study reveals that the increase in the level of urbanisation or growth in the number of urban centres increases slum population. In the state, the emerging trend of slum population growth highlights that slum population is increasing in the districts having high urbanisation growth rate and new emerging service centres like Deoghar, Lohardaga, Jamtara, Chatra and Giridih. The study highlights that there is decrease in average household size in slums. In few districts of Jharkhand, like in Deoghar, Giridih, Jamtara, there are still high slum population growth rate because these districts have the developing urban centres with lots of infrastructural investments and developments. In the case of Jharkhand, it can be concluded 
that the districts having high rate of urbanisation and developing urban centres (Deoghar, Jamtara, Khunti, Hazaribagh) had recorded high slum population growth rate in comparison to the previously urbanised districts and developed urban centres, where there is high population pressure.

\section{References}

Bhagat, R.B. (2011). Emerging Pattern of Urbanisation in India, Economic and Political Weekly, (34):10-12.

Census of India (2001). Metadata and Brief Highlights on Slum Population.

Census of India (2011). Final Population Totals, Jharkhand Series. http://censusindia.gov.in

Primary Census Abstract for Slum (2011).Office of the Registrar General \& Census Commissioner 2013, New Delhi.

Ramachandran, R. (1989).Urbanisation and Urban Systems in India. Oxford University Press, India.

Report of the Committee on Slum Statistics/Census (2010).Government of India, Ministry of Housing and Urban Poverty Alleviation, National Buildings Organization, New Delhi.

Report of the Committee on Slum Statistics/Census (2011).Government of India, Ministry of Housing and Urban Poverty Alleviation, National Buildings Organization, New Delhi.

Sawhney, Upinder (2013). Slum Population in India: Extent and Policy Response, International Journal of Research in Business and Social Science, 2 (9): 47-56.

\section{About the Authors}

Mr. Rahul Harshwardhan obtained his M.A. (2013) degree from Banaras Hindu University,
Varanasi. Currently, he is pursuing his $\mathrm{PhD}$ as a UGC Junior Research Fellow from the Department of Geography, Banaras Hindu University, Varanasi. His research theme is Morphology of Allahabad and Varanasi Cities: $A$ Comparative Analysis. He has attended and presented papers in various national and international conferences.

Dr V.K. Tripathi is an Associate Professor at the Department of Geography, Banaras Hindu University, Varanasi. He obtained his M.A. (1985) and Ph.D. (1991) degrees from Banaras Hindu University, Varanasi. From 1995 to 2004, he worked in two Government Colleges of Uttar Pradesh viz., Government P.G. College, Ranikhet and Government P.G. College, Mahammadabad, Ghazipur as Lecturer, Senior Lecturer and Reader. He joined $\mathrm{BHU}$ as a Lecturer in 2004 and became senior Lecturer in 2005 and Reader in 2008. His major fields of interests are Urban Geography, Applied Geography and Regional Planning. He has published more than 30 papers on these themes. Currently, he is teaching Urban Geography, Regional Planning, Economic Geography, Geographical thought and an Interdisciplinary course on Urban Studies. He is also a life member of various professional bodies.

\section{Acknowledgement}

This paper was presented in the $36^{\text {th }}$ Indian Geography Congress of NAGI held at the University of Rajasthan, Jaipur in November 2014. The paper was revised further on the basis of the feedback received from the presentation. We would like to thank all the participants of the congress. We also express our gratitude to the anonymous reviewers and the editor of this journal for their valuable feedback. 